\title{
A Demographic Study of Buying Spontaneity on E-Shoppers: Preference Kolkata (West Bengal)
}

\author{
Indrajit Ghosal \\ Institute of Management Study (IMS), Kolkata
}

\begin{abstract}
Online shopping or e-shopping has increased extremely in the past few years in India. Kolkata (West Bengal) is not so far behind. Lot of Online portals has been launched in india (like ebay, Amazon, Flipkart, Jabong, Myntra, Snapdeal etc.) and they have given a lot of opportunity and facility to buy products easily. It has improved the lifestyle of people in the country. Consumers tend to be attracted by the offers on the online shopping portals. This has resulted in increased impulsiveness among the buyers online. The study is an attempt to understand the effect of spontaneity among online buyers. For this research, online shoppers from Kolkata City were taken. The study indicated the fact that various factors contributed to the impulsiveness among buyers while they do online or e-shopping. Amongst them, unplanned tendency, online shopping mood and online shopping experience were identified as major factors. Demographic factors like age, gender, income and occupation of shoppers were also analyzed to know its effect on e-shopping spontaneous behavior.
\end{abstract}

Keywords: Online shopping, e-business, buying spontaneity, Demographic factors.

\section{INTRODUCTION}

7 he whole world has already been converted into a virtual world. People, institutions and organizations, all are doing their work virtually. The most impactful sector was the business sector. For the development of business in the virtual world, e-commerce was established. E-commerce covers a range of online business activities for products and services, both business-to-business and business-to-consumer, through the internet. E-commerce has already created massive differences in the whole world. The actual concept of globalization is achieved through e-commerce. People can buy and sell anything from anywhere in this world through e-commerce sites. According to internetlivestats.com, $40.4 \%$ of the overall population of this world is using internet till July, 2014. In 2013, the percentage was $37.9 \%$ [2]. So, it has been clear that the number of internet users is increasing day by day. There is no chance that the growth will decrease. As a matter of fact, the internet users are the ultimate target customers for the online shops.

Journal of Technology Management for Growing Economies Vol. 6, No. 2 October 2015 pp. $65-75$

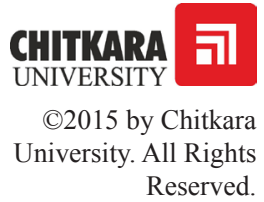




\section{Ghosal, I. $\quad$ E-Commerce in India}

Over the last two decades, rising internet and mobile phone penetration has changed the way we communicate and do business. E-commerce is relatively a novel concept. It is, at present, heavily leaning on the internet and mobile phone revolution to fundamentally alter the way businesses reach their customers. While in countries such as the US and China, e-commerce has taken significant strides to achieve sales of over 150 billion USD in revenue (the chart extracted from internet), the industry in India is, still at its infancy. However over the past

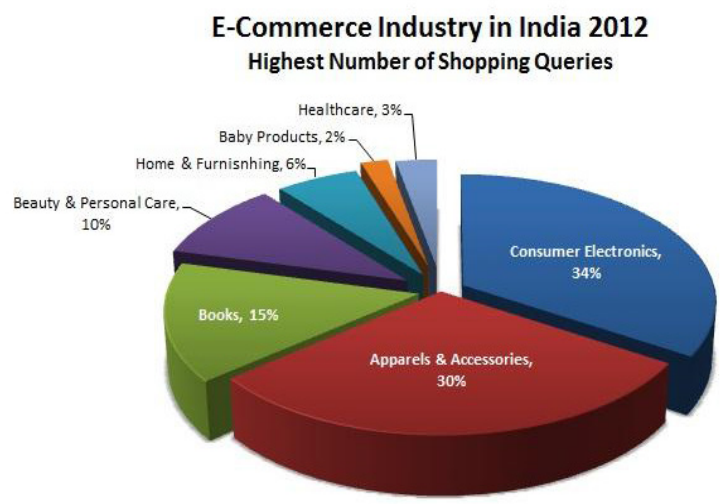

Source : Amit Misra (E-commerce in India: report)

few years, the sector has grown by almost 35\% CAGR from 3.8 billion USD in 2009 to an estimated 12.6 billion USD in 2013.Industry studies by IAMAI indicate that online travel dominates the e-commerce industry with an estimated $70 \%$ of the market share. However, e-retail in both its forms; online retail and market place, has become the fastest-growing segment, increasing its share from 10\% in 2009 to an estimated $18 \%$ in 2013. Calculations based on industry benchmarks estimate that the number of parcel check-outs in e-commerce portals exceeded million in 2013. However, this share represents a miniscule proportion (less than 1\%) of India's total retail market, but is poised for continued growth in the coming years. This growth is expected to be led by increased consumer-led purchases in durables and electronics, apparels and accessories, besides traditional products such as books and audiovisuals.

\section{Impulsive Buying behavior}

According to American Marketing Association fancy Buying is defined as "A purchase behavior that is assumed to be made without prior thought or planning." It is further said that this purchase involves an emotional reaction to the stimulus object.

Rook (1987) defined impulse purchasing as a sudden consumer experience,

Journal of Technology Management for Growing Economies, Volume 6, Number 2, October 2015 
often powerful and supported by a persistent urge to buy something immediately. The fancy to buy is hedonically complex and may stimulate emotional conflict. Also impulse buying is prone to occur with diminished regard for its consequences" fancy purchasing in online shoppers occurs as a result of factors like web site design, more products offered for sale, ease of navigation, ease of payment etc. But there is a lack of evidence, what is the effect of demographic factors on buying spontaneity among online shoppers? This study is done to examine such effect.

\section{LITERATURE REVIEW}

Online shopping is a way of shopping where the buyer can order a product or service by using internet. Virtual world is showing its impact as the days are passing by. We are literally living the virtual world. As this article is about the demographic study of buying spontaneity on E-Shoppers: within Kolkata (West Bengal). Some prior researches done on the subject of Online Shopping will be discussed in this segment. A significant amount of research work has been done on Online Shopping. A large group of researchers has pointed out the possibilities of Online Shopping. Others pointed out on the drawbacks and at the same time they provided necessary suggestion to make Online Shopping more useful for the online consumers.

Rook and Fisher (1995) conducted a study that provides conceptual and empirical evidence that consumers' normative evaluations moderate the relationship between the buying impulsiveness traits and related buying behaviors. They defined buying impulsiveness as a consumer's tendency to buy spontaneously, unreflectively, immediately and kinetically.

Liu and Arnett (2000) mentioned that the success of the e-commerce site depends on several factors such as Information, service quality, system use, playfulness and system design quality[15].

Online shopping offers to consumers which include ability to shop round the clock at anywhere, to search and browse products, to compare prices, and to make flexible electronic payments (Bhattacharjee Sarathi Partha,.et al., 2012;) investigates the relationship between globalization, ecommerce adoption or acceptance that lead to business performance and effectiveness .According to Ranganathan and Ganapathy (2002), several key dimensions to B2C websites are - Design functionality, Security, Privacy and Information quality [19].

Tinne (2010) conducted spontaneity buying has four characteristics; firstly it is unplanned purchase. Secondly, it is exposed to the stimulus, thirdly characteristics of impulse buying is the immediate nature of the behavior and lastly consumer experiences emotional and cognitive reactions.

There is a broad range of products and services marketed online (Kiang et al., 2011), yet none of the above classifications refers to marketing products through the internet.

Patna (2013), investigates the relationship between globalization, ecommerce
A Demographic Study of Buying 
adoption or acceptance that lead to business performance and effectiveness. Through privacy and security policies, developers are doing their best to put an end to this unethical practice. That will pave the way for its success.

Bashir et al. (2013) predicted impact of cultural values and life styles on desire buying behavior and the results suggested that there is significant impact of cultural values and life styles on spontaneous buying behavior. They found that the gender role is the only variable of cultural values and life style of customers where significant difference exists between male and female customers while making decisions. They also discussed that Impulse buying is influenced by time, location, personality, economic, and cultural factors.

\section{Objective of the Study}

From the above literature survey, the sole identified objective of this study is to identify the factors of buying spontaneity among online shoppers of Kolkata city.

\section{Research Methodology}

This study is based on the primary data and the author collected from the internet users of Kolkata (West Bengal). A questionnaire was given to the respondents. 150 respondents filled up the questionnaire.

\section{Data Collection Methodology}

The questionnaire is split into two sections. First section deals the demographic factors, Second section related to 15 items of buying rashness.

Data collection methodology involves both secondary and primary data. Primary data is collected using structured undisguised questionnaire. Responses are rated using 5 point Likert Scale, ranging from Totally Disagree (1) to Totally Agree (5). Secondary Data is collected from relevant journals, books, magazines, blogs, and conference proceedings.

\section{Sampling Plan}

Population: Customers who use internet across all demographic characteristics.

Research design: The study has been partly descriptive and partly diagnostic. The study is based on both primary and secondary data which has already been published in reputed journal and some news papers.

Sampling method: The study has tried to explore the factors which are influencing consumers' pre adoption of e-marketing. The questionnaire was distributed to both the users and non-users of e-marketing. A total of 150 questionnaires were distributed among the consumer of Kolkata \& greater Kolkata region in Eastern India.

Journal of Technology Management for Growing Economies, Volume 6, Number 2, October 2015 
Sampling Area: The area around Kolkata \& greater Kolkata region in West Bengal was the sampling area for this survey.

Sampling Frame: Customer List(s) of selected user who prefers online shopping.

\section{Sample Size: 150}

Data Collection: The study was consisting of both primary and secondary data.

i) Primary data Collection: This data were collected through well structured closed ended questionnaire.

ii) Secondary data: The data from secondary sources was collected through books, journals, reports, research studies, internet sources, magazines, newspapers, and bank websites to understand the basic concepts and literature pertaining to stress in general and occupational stress of bank

\section{Analysis and findings}

The demographics of the respondent is presented under the 5 attributes i.e. age, gender, education and income level. The following table(s) depicts the respondent's profile and the type of company they have selected for patronizing. As far as age is concerned, almost 5\% were $<18$ age ,50\% of the respondents were between 18-34 years old (50\%) followed by the age group of 35-49 years $(70 \%)$. On the other hand, 25 respondents $(25 \%)$ were $>50$ years of age group. Gender-wise, $100 \%$ of the respondents were male and only $50 \%$ were female. $2 \%$ of the respondents were below high school; followed by $3 \%$ higher secondary, Bachelor degree (40\%), post graduation $50 \%$ and Doctorate(s) only 55\%.

Table 1: Demographic profile of the respondents

\begin{tabular}{|l|l|l|}
\hline \multicolumn{3}{|c|}{ Based on Gender } \\
\hline 1 & M & 100 \\
\hline 2 & F & 50 \\
\hline \multicolumn{3}{|c|}{ Based On Age } \\
\hline 1 & $<18$ & 5 \\
\hline 2 & $>=18$ and $<35$ & 50 \\
\hline 3 & $>=35$ and $<50$ & 70 \\
\hline 4 & Above 50 & 25 \\
\hline \multicolumn{3}{|c|}{ Based on Education } \\
\hline 1 & Below High School & 2 \\
\hline
\end{tabular}

Journal of Technology Management for Growing Economies, Volume 6, Number 2, October 2015 


\begin{tabular}{|c|c|c|c|}
\hline \multirow[t]{4}{*}{ Ghosal, I. } & 2 & High School & 3 \\
\hline & 3 & Bachelor's Degree & 40 \\
\hline & 4 & Master's Degree & 50 \\
\hline & 5 & Doctorate & 55 \\
\hline 70 & $\begin{array}{l}\text { Based on Income } \\
\text { (Monthly) } \\
1 \text { Less than 20,000 } 146 \\
2 \text { 20,000-34,999 } 92 \\
335,000-49,99951 \\
4 \text { 50,000-70,00019 } \\
5 \text { Above 70,000 } 8\end{array}$ & $\begin{array}{l}\text { Monthly) } \\
\text { Less than } 10,000 \\
>=10,000 \text { and }<20,000 \\
>=20,000 \text { and }<35,000 \\
>=35,000 \text { and }<50,000 \\
>=50,000 \text { and }<80,000\end{array}$ & $\begin{array}{l}30 \\
30 \\
50 \\
30 \\
10\end{array}$ \\
\hline
\end{tabular}

\section{FACTOR ANALYSIS RESULTS}

A total of 150 respondents were surveyed using the questionnaire. The raw data was analyzed using SPSS 17.0 and factor analysis has been done to identify the factors which are influencing consumers' pre adoption of e-marketing. For doing that I have summarized 15 variables (as each question in Part - 2 (Consumer perception and their opinion) of survey questionnaire represent one variable) into smaller sets. Then data was subjected to principal component analysis. Hence, these 15 variables were reduced to four principal components through varimax rotation (Table 6). Items with factor loadings of 0.40 or higher were clustered together to form separate constructs. Here, the researcher had considered only those factors whose eigen-values is more than one, as significant. Table 5 indicates that, in the present test the Kaiser-Meyer-Olkin (KMO) measure of sampling Adequacy was 0.671 . Bartlett's test of Approx. Chi-Square $=428.383$ with a significance of 0.000 it provide support for validity of the factor analysis of the data set and indicates that, factor analysis is appropriate.

Table 2: KMO and Bartlett's Test

\begin{tabular}{|l|l|l|}
\hline \multicolumn{2}{|l|}{ Kaiser-Meyer-Olkin Measure of Sampling Adequacy. } & .671 \\
\hline Bartlett's Test of Sphericity & Approx. Chi-Square & 428.383 \\
\hline & & \\
\hline & Sig. & .000 \\
\hline
\end{tabular}

Journal of Technology Management for Growing Economies, Volume 6, Number 2, October 2015 
Table 3: Rotated Component Matrix

\begin{tabular}{|c|c|c|c|c|}
\hline & \multicolumn{4}{|c|}{ Component } \\
\hline & 1 & 2 & 3 & 4 \\
\hline $\begin{array}{l}\text { 1. E-Shopping is compatible } \\
\text { with my shopping needs }\end{array}$ & .906 & .108 & .154 & .145 \\
\hline $\begin{array}{l}\text { 2. E- Shopping is compatible } \\
\text { with my lifestyle }\end{array}$ & .736 & -.095 & -.121 & -.177 \\
\hline $\begin{array}{l}\text { 3. As I Concerned about the } \\
\text { security of Online Shopping or } \\
\text { e-shopping }\end{array}$ & -.086 & -.015 & .856 & -.147 \\
\hline $\begin{array}{l}\text { 4. I purchase online product as I } \\
\text { can shop according to my } \\
\text { convenience }\end{array}$ & -.085 & .831 & .171 & .119 \\
\hline $\begin{array}{l}\text { 5. I am concerned about the } \\
\text { privacy of e Shopping }\end{array}$ & -.062 & -.014 & .691 & .256 \\
\hline $\begin{array}{l}\text { 6. Using Online Shopping is a } \\
\text { sign of modernity }\end{array}$ & .812 & .098 & -.155 & .144 \\
\hline $\begin{array}{l}\text { 7. It is feel that credit-card } \\
\text { details may be compromised and } \\
\text { misused if I purchase product } \\
\text { through online }\end{array}$ & .263 & -.133 & .798 & -.123 \\
\hline 8. It is easy to use & .648 & -.043 & .118 & .482 \\
\hline $\begin{array}{l}\text { 9. Online Shopping is using my } \\
\text { parents }\end{array}$ & .837 & -.131 & .048 & -.180 \\
\hline $\begin{array}{l}\text { 10. Online Shopping is } \\
\text { compatible with our lifestyle }\end{array}$ & .872 & .157 & .097 & .082 \\
\hline $\begin{array}{l}\text { 11. I shop online as I can save } \\
\text { myself from market crowd }\end{array}$ & -.195 & .731 & .139 & .274 \\
\hline $\begin{array}{l}\text { 12. I shop online as I can take as } \\
\text { much time }\end{array}$ & .052 & .042 & -.061 & .794 \\
\hline $\begin{array}{l}\text { 13. I might not get what I } \\
\text { ordered through e- shopping }\end{array}$ & .021 & .899 & -.173 & -.066 \\
\hline $\begin{array}{l}\text { 14. The quality of merchandise } \\
\text { over Internet is }\end{array}$ & .147 & .881 & -.209 & -.055 \\
\hline $\begin{array}{l}\text { 15. Getting good after sales } \\
\text { service }\end{array}$ & .323 & .570 & -.184 & -.202 \\
\hline
\end{tabular}

A Demographic Study of Buying 
Ghosal, I.

Extraction Method: Principal Component Analysis.

Rotation Method: Varimax with Kaiser Normalization.

a. Rotation converged in 5 iterations.

In the Rotated Component Matrix table, each number represents the partial correlation coefficient between variable and rotated component. All the variables having factor loadings of greater than .50 for a given component define the component. The following (Table 4) displays the variables constituting the 4 components.

Table 4: Components

\begin{tabular}{|c|c|c|c|c|}
\hline $\begin{array}{l}\text { S. } \\
\text { No. }\end{array}$ & Factors & Eigen Value & Variance & $\begin{array}{c}\text { Cumulative } \\
\text { Variance }\end{array}$ \\
\hline \multirow[t]{7}{*}{1} & Shopping desires & 4.217 & 27.704 & 27.704 \\
\hline & $\begin{array}{l}\text { E-Shopping is compatible } \\
\text { with my shopping needs }\end{array}$ & & .906 & \\
\hline & $\begin{array}{l}\text { E- Shopping is compatible } \\
\text { with my lifestyle }\end{array}$ & & .736 & \\
\hline & $\begin{array}{l}\text { Using Online Shopping is a } \\
\text { sign of modernity }\end{array}$ & & .812 & \\
\hline & It is easy to use & & .648 & \\
\hline & $\begin{array}{l}\text { Online Shopping is using my } \\
\text { parents }\end{array}$ & & .837 & \\
\hline & $\begin{array}{l}\text { Online Shopping is compati- } \\
\text { ble with our lifestyle }\end{array}$ & & .872 & \\
\hline \multirow[t]{5}{*}{2} & Convenience $\&$ belief & 3.285 & 21.538 & 49.243 \\
\hline & $\begin{array}{l}\text { I shop online as I can take as } \\
\text { much time }\end{array}$ & & .831 & \\
\hline & $\begin{array}{l}\text { I might not get what I ordered } \\
\text { through e- shopping }\end{array}$ & & .731 & \\
\hline & $\begin{array}{l}\text { I might not get what I ordered } \\
\text { through online shopping }\end{array}$ & & .899 & \\
\hline & $\begin{array}{l}\text { The quality of merchandise } \\
\text { over Internet is }\end{array}$ & & .881 & \\
\hline \multirow[t]{4}{*}{3} & Security \& threat & 2.025 & 13.959 & 63.201 \\
\hline & $\begin{array}{l}\text { I am concerned about the pri- } \\
\text { vacy of e Shopping }\end{array}$ & & .856 & \\
\hline & $\begin{array}{l}\text { I am concerned about the se- } \\
\text { curity of Online Shopping }\end{array}$ & & .856 & \\
\hline & $\begin{array}{l}\text { I am concerned about the pri- } \\
\text { vacy of e Shopping }\end{array}$ & & .691 & \\
\hline
\end{tabular}

Journal of Technology Management for Growing Economies, Volume 6, Number 2, October 2015 


\begin{tabular}{|l|l|l|l|l|}
\hline & $\begin{array}{l}\text { It is feel that credit-card de- } \\
\text { tails may be compromised and } \\
\text { misused if I purchase product } \\
\text { through online }\end{array}$ & .798 & \\
\hline 4 & agility & 1.197 & 8.093 & 71.295 \\
\hline & $\begin{array}{l}\text { I shop online as I can take as } \\
\text { much time }\end{array}$ & .794 & \\
\hline
\end{tabular}

A Demographic Study of Buying

\section{CONCLUSION}

The objective of this study were to investigate the customer spontaneity towards online shopping with respect to Kolkata City and to study variations in the buying rashness with respect to across age, income, education and gender wise. In addition, this study shows that the average customer of Kolkata city in our sample was not very conscious regarding online/eshopping shopping, it is found that; 35-50 age group and above 3.5 lac income group consumers are very impulsive, about online shopping which is related to on the spot online offers for getting customer satisfaction in Kolkata. Shopping is humorous activity for them. Customers are mostly concerned with their shopping practices and are not promotion conscious. In addition, this study shows that the average customer of Kolkata in our sample was very conscious about online shopping, people are very conscious about extra facilities and services provide by online shopping; they also want clarity in condition from online shopping. Students are quite conscious about any type of satisfaction factors.

(i) Shopping desires (ii) Convenience \& belief (iii) Security \& threat (iv) Agility

Thus the companies looking forward to transact online and the existing companies already providing e-shopping facilities have to focus on all the above factors. The most prominent and vital characteristic for adoption of any new technology, is generating awareness among the customers and educating them about that specific technology. Hence, if the consumers of West Bengal are not adopting Online Shopping, it may be because they are not aware about such a service being available and the added value that it offers. They should simplify the initial setup process and also provide troubleshooting.

Convenience \& belief is the second factor considered for this research study. In order to successfully implement the Online Shopping, companies must ensure that the services are easy, simple, rapid and of sufficiently high 

user friendly website with a good graphical user interface and easy to use navigation tools will certainly help in this regard.

Security and threat is another important factor. The element of risk in this context would relate to the security of transacting for consumers and determine the acceptability rate of this alternative delivery channel in the long run. To control the risk factor marketers has to provide consumer reassurance and information. Improve application as well as online payment information security and privacy, train \& advise e-customers for following secure online transaction practices and other risk related factors. The payment system still needs to be improved. The most challenging issue would be building the trust among the consumers about the online shops. The people know the positive sides of online shopping. But they do not know whether their privacy or security is there or not. Develop easy \& user friendly customer support applications for flexibility.

\section{LIMITATIONS \& SCOPE OF FUTURE RESEARCH}

The main objective of this research is to identify the factors of buying spontaneity among online shoppers of Kolkata city. Used only 150 respondents to draw inference on the population which is a very small number compared to the massive population of the research. Future researchers can use the findings of this paper for further research and can extend their studies to other neighboring states like Bihar, Jharkhand, Sikkim, UP etc where the use of the technology is still in the nascent stage.

\section{REFERENCES}

Sharma, A. (2012) 'E-commerce in India', Retrieved from: http://dazeinfo.com/2013/01/29/ ecommerce-in-india-consumers-interest-went-up-by-128-in-2012-report/.

Rook, D.W. and Fisher, R. J. (1995), 'Normative influences on impulsive buying behavior', Journal of Consumer Research, 22:3, pp. 305-313.

Liu, C \& Arnett K.P. (2000), 'Exploring the factors associated with website success in the context of electronic commerce', Information \& Management, 38 (2000), pp. 23-33. http://articles.timesofindia.indiatimes.com/2013-11-14/internet/44073307 1 internetand-mobile-association- internet-penetration-rural-india. http://dx.doi.org/10.1016/S03787206(00)00049-5.

Ranganathan, C. \&Ganapathy, S. (2002), 'Key dimensions of Business-to-Consumer websites', Information and Management, 38 (2002), pp. 457-465.

Sun, T. and Wu, G. (2011) 'Trait predictors of online impulsive buying tendency: a hierarchical approach', Journal of Marketing Theory and Practice, 19:3, pp. 337-346.

Tinne, W. S. (2010), 'Impulse purchasing: a literature overview', ASA University Review, 4:2, pp. 65-73.

Bhattacharjee, S. P., Saha, K. A. and Begum, A. S. (2012) 'The application of E-commerce in Business Application: Their Problems and Prospects', International Journal of Computer

Journal of Technology Management for Growing Economies, Volume 6, Number 2, October 2015 
Applications (0975 - 8887), 49:10, Retrieved from http://www.euroasiapub.org/IJRESS/ Sep2013/4.pdf.

Patna, H. C. (2013) 'Is online shopping booming in india? - an empirical study', Retrieved fromhttp://www.mbaskool.com/business-articles/marketing/7695-is-online-shoppingbooming-in-india-an-empirical-study.html.

Bashir, S., Zeeshan, M., Sabbar, S., Hussain, R. I. and Sarki, I. H. (2013), 'Impact of Cultural Values and Life Style on Impulse Buying Behavior: A case study of Pakistan', International Review of Management and Business Research, 2:1, pp. 193-200.

Indrajit Ghosal, Assistant Professor, Institute of Managment Study, Kolkata. Email: ghosal.m1981@gmail.com.
A Demographic Study of Buying 